\title{
Study of ectopic pregnancy in a tertiary care centre
}

\author{
Nitesh Meena*, Radheshyam Bairwa, Savitri Sharma
}

Department of Obstetrics and Gynecology, Jhalawar Medical College, Jhalawar, Rajasthan, India

Received: 18 October 2019

Revised: 19 November 2019

Accepted: 28 November 2019

\section{*Correspondence:}

Dr. Nitesh Meena,

E-mail: niteshmeena85@gmail.com

Copyright: () the author(s), publisher and licensee Medip Academy. This is an open-access article distributed under the terms of the Creative Commons Attribution Non-Commercial License, which permits unrestricted non-commercial use, distribution, and reproduction in any medium, provided the original work is properly cited.

\section{ABSTRACT}

Background: Ectopic pregnancy is an obstetric emergency with high morbidity and mortality. Incidence of ectopic pregnancies has been increasing in last two to three decades with reduction in mortality. The presenting symptoms include irregular vaginal bleeding. The present study was undertaken to study the clinical features of ectopic pregnancies in a tertiary care hospital.

Methods: The present study on ectopic pregnancies was carried out in department of obstetrics and gynaecology, jhalawar medical college, Jhalawar, Rajasthan, India from January 2019 to October 2019. All patients admitted with diagnosis of ectopic pregnancy, either ruptured or unruptured where included in the study.

Results: Total 52 patient of ectopic pregnancy were studies. Majority $(63.46 \%)$ of patients belong to the age group 21-30 years. Ectopic pregnancy was most commonly noted in nulliparous woman (44.23\%) Majority of the case (31\%) had no risk factors among remaining (34.61\%), previous MTP (17\%), (17-30\%) previous ectopic (9\%) and PID (15-38\%) were identified risk factors. Ampulla (75\%) was the most common site for ectopic pregnancy. 57\% of the cases were on the right side. The common presenting complaints were pain in abdomen ( $81 \%$ ) bleeding/ spotting per vaginal $(42 \%)$. There was no mortality.

Conclusions: Surgical treatment was done more often because of patients reporting late to the hospital screening of high-risk case, early diagnosis and early intervention reduce the morbidity and mortality in ectopic pregnancies.

Keywords: Ampulla, Ectopic, Emergency, Laparotomy, Pain in abdomen, Pregnancy

\section{INTRODUCTION}

An ectopic pregnancy is one in which the fertilize ovum become implanted in a site other than the normal uterine cavity ${ }^{1}$ It is one of the common causes of maternal morbidity and mortality in first trimester of pregnancy. ${ }^{2}$ Worldwide ectopic pregnancy complicated 1 to $2.0 \%$ of all pregnancies. ${ }^{3}$ There is an overall increase in incidence of ectopic tubal pregnancy (ETP) and this is probably due to increase awareness, advanced diagnostic tools like trans-vaginal ultrasonography (TVUSG) and estimation of beta subunit of human chorionic gonadotrophin (beta $\mathrm{HCG}$ ) in serum. ${ }^{4}$ Several risk factors have been identified for ectopic pregnancies vim. Pelvic inflammatory previous pelvic surgery, previous ectopic pregnancy, intrauterine device usage, induction of ovulation, smoking etc. The classic symptom triad of ectopic pregnancy is pain abdomen, amenorrhea, and vaginal bleeding. ${ }^{5}$

Evidence of an empty uterus, detection of adnexal masses and free peritoneal fluid and adnexal ring are ultrasonography sings of ectopic pregnancy. ${ }^{6}$

Between 93-97\% of ectopic pregnancies are located in a fallopian tube. ${ }^{7}$ Of these, $13 \%$ are located in the isthmus, 
$75 \%$ are located in the ampulla, and $12 \%$ in the fimbriae. ${ }^{8}$ Nearly $2 \%$ of all the ectopic pregnancies become established in other areas including the ovary, the cervix or the intra-abdominal region. ${ }^{9}$ Early treatment of an ectopic pregnancy with methotrexate is a viable alternative to surgical treatment. ${ }^{10,11}$ Surgical treatment becomes necessary if rupture has already occurred. Laparoscopy or laparotomy is performed in such cases and the affected fallopian tube is incised with removal of only the pregnancy (salpingostomy) or the affected tube is removed with the pregnancy (salpingectomy). The present study was undertaken to study the clinical features of ectopic pregnancies in a tertiary care hospital.

\section{METHODS}

The present study on ectopic pregnancies was carried out in department of obstetrics and gynaecology, Jhalawar medical college, Jhalawar, Rajasthan, India from January 2019 to October 2019. The case sheets of patients with ectopic pregnancies were traced through the labour room registers and operation theatre registers. Data collection tool was used to collect the different information. Face to face interviews were conducted using data collection tool by the investigator including detailed history taking and relevant physical examination. A detailed history was taken from the patient (if the patient was in shock the history was taken retrospectively). After taking history physical examination was done especially for vital signs, abdominal examination, per vaginal examination, cervical excitation test and culdocentesis when needed. The basic investigations including haemoglobin, renal function test, blood grouping and $\mathrm{Rh}$ typing, urine pregnancy test and ultrasound examination were done in all patients. Additional investigations like serum beta hCG, doppler study, CT, MRI were ordered in case of doubtful diagnosis. Culdocentesis and urine pregnancy test were carried out in hemodynamically unstable patients and those who were stable USG was done. Subsequently emergency laparotomy was done in hemodynamically unstable patients with provisional diagnosis of ruptured ectopic pregnancy. All the surgeries were done by laparotomy under spinal/general anesthesia. Post operatively HPE reports were collected from the pathology department and final diagnosis was made. Information regarding patient profile, risk factors, sterilisation status, use of other contraceptive methods, presenting symptoms and signs, physical examination, ultrasound findings, types of treatment, per operative findings, no of transfusions, post-operative morbidity and length of hospital stay were analysed. Detailed analysis was done using simple descriptive statistics and presented as percentages in tables. Clinical details were noted in a predefined proforma.

\section{Inclusion criteria}

All the patients admitted with a diagnosis of ectopic pregnancy, either ruptured or unruptured were included in the study.

\section{Exclusion criteria}

Patients diagnosed as having intrauterine pregnancy and all the cases of ectopic pregnancy with medical management were excluded from the study. The study was initiated after approval from the institutional ethics committee.

\section{RESULTS}

Total 52 patients with diagnosis of ectopic pregnancy were admitted in our hospital in the study period. Table 1 shows that the incidence of ectopic pregnancy is higher in 21-30 years of age $(63.46 \%)$. Youngest age was 18 years. Highest age limit was 45 years. Highest incidence in the age group of 21 to 30 years. Donates the peak of the fertile period after marriageable age.

Table 1: Case of ectopic pregnancy in relation to age $(\mathrm{N}=52)$.

\begin{tabular}{|lll|}
\hline Age group (years) & No. of cases & Percentage \\
\hline $15-20$ & 2 & $3.84 \%$ \\
\hline $21-25$ & 20 & $71.15 \%$ \\
\hline $26-30$ & 13 & $25.0 \%$ \\
\hline $31-35$ & 9 & $17.30 \%$ \\
\hline $36-40$ & 7 & $13.43 \%$ \\
\hline $41-45$ & 1 & $1.92 \%$ \\
\hline Total & $\mathbf{5 2}$ & $\mathbf{1 0 0 \%}$ \\
\hline
\end{tabular}

Table 2: Distribution of cases based on parity.

\begin{tabular}{|lll|}
\hline Party & Number of cases & Percentage \\
\hline Nulliparous & 23 & $44.23 \%$ \\
\hline 1 & 15 & $28.84 \%$ \\
\hline 2 & 10 & $19.23 \%$ \\
\hline 3 & 4 & $7.69 \%$ \\
\hline Total & $\mathbf{5 2}$ & $\mathbf{1 0 0 \%}$ \\
\hline
\end{tabular}

Table 2 shows that ectopic pregnancy was most commonly noted in nulliparous women $(44.23 \%)$.

Table 3: Risk factors of ectopic pregnancy.

\begin{tabular}{|lll|}
\hline Risk factors & $\begin{array}{l}\text { Number of } \\
\text { cases }(\mathbf{N}=\mathbf{5 2})\end{array}$ & \begin{tabular}{l} 
Percentage \\
\hline Unknown
\end{tabular} \\
\hline History of MTP & 9 & $34.61 \%$ \\
\hline History of PID & 8 & $17.30 \%$ \\
\hline $\begin{array}{l}\text { Previous history of } \\
\text { ectopic pregnancy }\end{array}$ & 5 & $15.38 \%$ \\
\hline $\begin{array}{l}\text { History of caesarean } \\
\text { section }\end{array}$ & 6 & $9.61 \%$ \\
\hline Infertility treatment & 6 & $11.53 \%$ \\
\hline
\end{tabular}

Table 3 shows risk factors of ectopic pregnancy. In this study majority of the cases $18(34.61 \%)$ had no risk factors. $9(17.30 \%)$ had history of medical termination of 
pregnancy, 8 (15.38\%) had history of PID, 5 (9.61\%) had previous history of ectopic pregnancy, 6 (11.53\%) had history of caesarean section and $6(11.53 \%)$ following infertility treatment.

Table 4: Distribution of cases based on the site of ectopic pregnancy.

\begin{tabular}{|lll|}
\hline $\begin{array}{l}\text { Site of ectopic } \\
\text { pregnancy }\end{array}$ & $\begin{array}{l}\text { Number of } \\
\text { cases }\end{array}$ & Percentage \\
\hline Ampullary & 39 & $75 \%$ \\
\hline Isthmal & 7 & $13.46 \%$ \\
\hline Fimbrial & 4 & $7.69 \%$ \\
\hline Cornual & 1 & $1.925 \%$ \\
\hline Ovary & 1 & $1.92 \%$ \\
\hline Total & $\mathbf{5 2}$ & $\mathbf{1 0 0 \%}$ \\
\hline
\end{tabular}

Table 4 shows that most common site of ectopic pregnancy was in ampulla of fallopian tube $75 \%$. Isthmic tubal pregnancy was seen in $13.46 \%$ and $7.69 \%$ cases had fimbrial pregnancy. Only $1.92 \%$ had both corneal and ovary pregnancy.

Table 5: Clinical presentation.

\begin{tabular}{|lll|}
\hline Symptoms & Number of cases & Percentage \\
\hline Amenorrhea & 28 & $54 \%$ \\
\hline Abdominal pain & 42 & $81 \%$ \\
\hline Bleeding & 22 & $42 \%$ \\
\hline Shock & 10 & $19.23 \%$ \\
\hline UPT positive & 41 & $78.84 \%$ \\
\hline
\end{tabular}

Table 6: Distribution of the cases according to the involved side of fallopian tube in ectopic pregnancy.

\begin{tabular}{|lll|}
\hline $\begin{array}{l}\text { Side of fallopian } \\
\text { tube }\end{array}$ & $\begin{array}{l}\text { Number of cases } \\
(\mathbf{N}=\mathbf{5 2})\end{array}$ & Percentage \\
\hline Right & 30 & $57.69 \%$ \\
\hline Left & 22 & $42.30 \%$ \\
\hline Total & $\mathbf{5 2}$ & $\mathbf{1 0 0 \%}$ \\
\hline
\end{tabular}

Table 7: Distribution of the cases based on the surgical procedure done.

\begin{tabular}{|lll|}
\hline Procedure & $\begin{array}{l}\text { Number } \\
\text { of cases }\end{array}$ & Percentage \\
\hline Unilateral salpingectomy & 29 & $55.76 \%$ \\
\hline Bilateral salpingectomy & 8 & $15.38 \%$ \\
\hline $\begin{array}{l}\text { Unilateral salpingo- } \\
\text { oophorectomy }\end{array}$ & 11 & $21.15 \%$ \\
\hline $\begin{array}{l}\text { Salpingo-oophorectomy } \\
\text { with contralateral tubectomy }\end{array}$ & 4 & $7.69 \%$ \\
\hline Total & $\mathbf{5 2}$ & $\mathbf{1 0 0 \%}$ \\
\hline
\end{tabular}

Table 5 shows majority of women presented with pain abdomen (81\%), amenorrhea (54\%), bleeding P/v (42\%). Patient presented with shock $19.23 \%$. Urine pregnancy test (UPT) was positive in $78.84 \%$. Pallor was a significant finding in $65 \%$ of cases who required blood transfusion.

Table 6 shows that right side tubal pregnancy is more common than left side.

Table 7 shows all patients underwent laparotomy. Significantly more cases underwent unilateral salpingectomy $(55.76 \%)$, followed by unilateral salpingooophorectomy. $\quad 15.38 \%$ underwent bilateral salpingectomy as they had previous tubal sterilization.

\section{DISCUSSION}

Ectopic pregnancy is the most common cause of death in the first trimester of pregnancy in developing countries. In the present study the majority of the patients belonged to the age group 21-25 years $(\mathrm{N}=52,71.15 \%)$. This is similar to the study by Rakhi etal in which the most common age group affected were $20-25$ years $(68.57 \%) .^{12}$ This is in contrast to the study by Kumar A et al and Poonam et al in which the peak age incidence was 26-30 years. $^{13,14}$

Various studies have showed the symptoms of abdominal pain was seen in $70.97 \%$ to $97.3 \%$ of the patients. In the present by Shaikh BN et al, typical history of amenorrhea and abdominal pain was found in $46(77 \%)$ women, 22 $(38 \%)$ were in a state of shock. ${ }^{15}$ In the study by Hassan $\mathrm{N}$ et al abdominal pain was seen in (44) $70.97 \%$, amenorrhea (32) $51.61 \%$ and irregular vaginal bleeding (16) $25.81 \% .{ }^{16}$ Majority $80.6 \%$ (75/93) presented with abdominal pain and $35.8 \%$ (33/93) presented with vaginal bleeding in study by Ao Igwegbe et al. ${ }^{17}$ In comparison to all these studies the present study had $81 \%$ of the patients had pain abdomen, 54\% had amenorrhea, $42 \%$ had vaginal bleeding.

In the present study, previous medical abortions and previous lower segment caesarean section were present in $17.30 \%$ and $11.53 \%$ patients respectively, which is quite comparable to the studies done by Asuri SS et al, Yadav et al, Priyadarshini et al, Saha et al. ${ }^{18-21} \mathrm{We}$ found that history of infertility treatment was there in $11.53 \%$ patients almost similar to the studies of Asuri SS et al. ${ }^{18}$ In our study history of PID was present in $15.38 \%$ patients. In our study $9.61 \%$ patients had previous ectopic pregnancy, comparable to the studies of Priyadarshini et al.

The commonest site of ectopic pregnancy in our study was the ampullary region of the fallopian tube. Incidence of ectopic was found to be highest among multiparous women. History of pelvic inflammatory disease is very difficult to elicit, since most of them have a subclinical infection and do not visit a health care centre for treatment. Lower abdominal pain was the most common clinical presentation in our subjects.

There was no maternal mortality due to ectopic pregnancy in the present study as in other studies. ${ }^{15,20,22}$ 
This may be as a result of prompt and proper management of the patients after reporting to the hospital. Hence it is seen clearly that while there is an increase in incidence of ectopic pregnancy, mortality has reduced significantly which can be because of improved diagnostic and treatment modalities.

\section{CONCLUSION}

Ectopic pregnancy should be suspected in a woman of reproductive age presenting with the triad of pain in abdomen, amenorrhea and vaginal bleed irrespective of the status of tubal ligation. Surgical treatment was done more often because of patients reporting late to the hospital. Screening of high-risk cases, early diagnosis and early intervention reduces the morbidity and mortality in ectopic pregnancies.

\section{Funding: No funding sources}

Conflict of interest: None declared

Ethical approval: The study was approved by the Institutional Ethics Committee

\section{REFERENCES}

1. Kumar P, Malhotra N. Ectopic pregnancy. Jefcoat's principles. Obstet Gynecol. 2008:142-59.

2. Mahheob U, Masher SH. Management of ectopic pregnancy, a two-year study. Ayub Meb Coll Abbotthad. 2006;18(4):34-7.

3. Jurkvic D. Diagnosis and management of ectopic pregnancy. British Med J. 2011;342:3397.

4. Chatterjee S, Dey S, Chowdhury RG. Ectopic pregnancy in previously infertile women - subsequent perregnancy outcome after laparoscopic management. Al A meen J Med Sci. 2009;2(1):67-72.

5. Prasanna B, Jhansi CB, Swathi K, Shaik MV. A study on risk factors and clinical presentation of ectopic pregnancy in women attending a tertiary care centre. IAIM. 2016;3(1):90-6.

6. Berek S. Bereck and Novak's Gynecology, 15th Ed; 2012:628-630.

7. Kirk E, Bottomley C, Bourne T. Diagnosing ectopic pregnancy and current concepts in the management of pregnancy of unknown location. Hum Reprod. Update. 2014:20(2):250-61.

8. Zane SB, Kieke BA, Kendrick JS, Bruce C. Surveillance in a time of changing health care practices: estimating ectopic pregnancy incidence in the united states. Matern Child Health J. 2002;6:227.

9. Crochet JR, Bastian LA, Chireau MV. Does this woman have an ectopic pregnancy? The rational clinical examination systematic review. JAMA. 2013;309(16):1722-9.

10. Ankum VM, Mol BW, Van der veen F. Risk factors for ectopic pregnancy: a meta-analysis. Fertil Steril. 1996;65:1093-9.

11. Mahboob U, Mazhar SB. Management of ectopic pregnancy: a two-year study. J Ayub Med Coll Abbottabad. JAMC. 2006;18(4):34-7.

12. Rakhi, Mital PL, Nupur H, Agarwal A, Makkar P, Fatima A. Ectopic pregnancy: a devastating catastrophe. Sch J App Med Sci. 2014;2(3A):903-7.

13. Arup KM, Niloptal R, Kakali SK. Pradip KB. Ectopic pregnancy an analysis of 180 cases. J Indian Med Assoc. 2007;105:308-14.

14. Poonam Y, Prety D, Banerjee B. Ectopic pregnancy two years review from BPKIHS, Nepal. Kathmandu University Med J. 2005;3:365-9.

15. Shaikh NB, Shaikh S, Shaikh F. A clinical study of ectopic pregnancy. J Ayub Med Coll Abbottabad. 2014;26(2):178-81.

16. Hassan N, Zaheen Z, Jatoi N. Risk factors, clinical presentation and management of 62 cases of ectopic pregnancy at tertiary care centre. JLUMHS. 2009;8(3):238-41.

17. Igwegbe AO, Eleje GU, Okpala BC. An appraisal of the management of ectopic pregnancy in a Nigerian tertiary hospital. Ann Med Health Sci Res. 2013;3(2):166-70.

18. Asuri SS, Kalpana P. A clinical study of ectopic pregnancy. Int J Reprod Contracept Obstet Gynecol. 2016;5(11):3750-3.

19. Yadav A, Prakash A, Sharma C, Pegu B, Saha MK. Trends of ectopic pregnancies in Andaman and Nicobar Islands. Int J Reprod Contracept Obstet Gynecol. 2017;6:15-9.

20. Priyadarshini B, Padmasri, Jnaneshwari TL, Sowmya KP, Bhatara U, Hema V. Ectopic pregnancy: a cause for maternal morbidity. Int $\mathbf{J}$ Reprod Contracept Obstet Gynecol. 2017;5(3):700-4.

21. Saha PK, Gupta P, Goel P, Sehgal A, Huria A, Kataria S, et al. Ectopic Pregnancy: a diagnostic dilemma Int. J Reprod Contracept Obstet Gynecol. 2016;5(2):367-70.

22. Jophy R, Thomas A, Mhaskar A. Ectopic Pregnancy 5 years' experience. J Obst Gyn India. 2002;52(4):55-8.

Cite this article as: Nitesh M, Bairwa R, Sharma S. Study of ectopic pregnancy in a tertiary care centre. Int J Reprod Contracept Obstet Gynecol 2020;9:2125 